\title{
Can ELABELA be a novel target in the treatment of chronic lymphocytic leukaemia?
}

\author{
Didar Yanardag Acik ${ }^{1 *}$ (D) Mehmet Bankir², Filiz Alkan Baylan ${ }^{3}$ and Bilal Aygun ${ }^{4}$
}

\begin{abstract}
Background: It has been shown that $\mathrm{bcl} 2, \mathrm{bcl}-\mathrm{XL}$ and $\mathrm{mcl}-1$ protein levels are high in chronic lymphocytic leukemia cells, and resultantly, apoptosis does not occur chronic lymphocytic leukemia cells. Apelin and apela (ELABELA/ELA/Toddler) are two peptide ligands for a class A G-protein coupled receptor called apelin receptor. Studies have shown that ELA inhibits apoptosis by inhibiting apoptotic proteins and activating anti-apoptotic proteins. Proteins and genes involved in apoptosis are valuable for targeted cancer therapy. We hypothesized that serum levels may be increased in patients with chronic lymphocytic leukemia based on the antiapoptotic effect of ELA. We compared serum ELABELA levels of healthy volunteers and patients with chronic lymphocytic leukemia. We aimed to draw attention to a new molecule worthy of research in targeted cancer treatment.

Methods: Forty two untreated CLL patients and 41 healthy volunteers were included in the study. Serum ELA levels were measured by using enzyme-linked immunosorbent assay kits (Dhanghai Sunred Biological Technology co. Ltd), automated ELISA reader (Thermo Scientific, FiNLAND) and computer program (Scanlt for Multiscan F.C.2.5.1) in accordance with the manufacturer's instructions. Statistical analysis was done by Statistical Package for Social Sciences for Windows 20 (IBM SPSS Inc., Chicago, IL) ve MedCalc programs. ELA and variables related to CLL were correlated with Spearman correlation anlysis test. ROC analysis and Youden index method were used to determine a cut off point for ELA. All p-values were 2-sided with statistical significance at 0.05 alpha levels.
\end{abstract}

Results: In our study, we found that serum ELA levels were significantly higher in patients with CLL.

Conclusions: This study highlights that ELA targeting may be a potential therapeutic option for treating CLL.

Keywords: ELABELA, Apelinergic system, Chronic lymphocytic leukaemia, Apoptosis

\section{Background}

Chronic lymphocytic leukaemia (CLL) is the most frequent type of leukaemia in adults worldwide [1]. It is a malignancy characterised by accumulation of small, neoplastic $\mathrm{CD} 5^{+} \mathrm{B}$ cells with a mature appearance in blood, bone marrow and secondary lymphoid tissues, lymphadenopathy and splenomegaly [2]. In contrast to malignant cells of other B lymphocytes, the majority of CLL cells are arrested in the G0/G1 cell transformation phase because they do not possess proliferative capacity. Therefore, CLL does not occur as a result of excessive B

\footnotetext{
* Correspondence: didaryanardag@gmail.com

${ }^{1}$ Department of Internal Medicine and Haematology, Adana City Education and Research Hospital, Mithat Özsan Bulvarı Kışla Mah. 4522 Sok. No:1, 01260 Yüreğir, Adana, Turkey

Full list of author information is available at the end of the article
}

cell proliferation but because of defective apoptosis [3] The mechanism of apoptosis is complex and involves two separate regulatory pathways: the intrinsic and extrinsic pathways. The intrinsic pathway is regulated by the bcl-2 family. Bcl-2 itself is an anti-apoptotic protein and is part of a complex including MCL-1, BCL-XL, BCL-W and BFL-1, all of which support cell survival. The bcl-2 family members, including BAX and BAK, which are homo-oligomerized when activated and regulate outer mitochondrial membrane permeability, cause irreversible caspase activation and subsequently apoptotic cell death [4].

Studies have suggested that bcl 2, bcl-XL and mcl-1 protein levels are high in CLL cells, and therefore, apoptosis does not occur in CLL cells [3, 4]. 
The clinical course of CLL considerably varies. This variability has been linked to mutations in TP53. TP53 is the most important predictor of response to therapy and prognosis. It has been found that TP53 undergoes mutation in half of all human cancer cases and that loss of regulatory function of TP53 leads to oncogenesis. Loss of function of TP53 is considered to be an important event in tumour formation and is also associated with chemotherapy resistance and poor prognosis in many cancers [5].

Therefore, mechanisms that activate or inhibit TP53 have been the focus of research in targeted cancer therapy.

Apelin and ELA are two peptide ligands for a class A Gprotein coupled receptor called apelin receptor (AR/APJ/ APLNR). These ligands function by binding to this receptor; this is known as the apelinergic system (Apelin/APJ system). The binding of both endogenous peptides to AR results in similar physiological effects [6]. It is well known that the Apelin/APJ system can regulate apoptosis in various cell types and subsequently mediate the formation and development of related diseases. Recent evidence suggests that the Apelin/APJ system affects apoptosis in various diseases through different signalling pathways. Pre-treatment of cardiomyocytes with apelin-13 effectively inhibits apoptosis caused by glucose withdrawal and can significantly increase Akt and mTOR phosphorylation by upregulating $\mathrm{Bcl}-2$ and downregulating Bax and cleaved caspase- 3 expression. The Apelin/APJ system also upregulates the expression of Bcl-2 and downregulates the expression of Bax protein [7-11].

ELA (also known as Ende, Elabela and Toddler) was first identified in a gene expression panel for new mouse endoderm-specific genes and is evolutionally conserved among vertebrates. In zebrafish, loss of ELA disrupts mesendodermal cell movement during gastrulation, resulting in defects in endoderm differentiation and heart development and in posterior malformations. ELA acts as an endogenous ligand for APLNR, its G-proteinlinked receptor, and ELA and APLNR have been shown to direct angioblast migration to control the vascular pattern in zebrafish embryos [12-14]. ELA is highly expressed in human blastocysts prior to implantation and contributes to the pluripotency of human embryonic stem cells (hESCs) via an alternative receptor [15].

The non-coding region of ELA has been shown to play a role in the regulation of apoptosis induced by p53-mediated DNA damage in mouse embryonic stem cells. ELA downregulates the interaction between heterogeneous nuclear ribonucleoprotein L (hnRNPL) and p53 [16].

In this study, we aimed to investigate the relationship between ELA and CLL because the apelinergic system blocks the caspase system that induces apoptosis and validate the anti-apoptotoic effects of ELA that have been demonstrated in previous studies.

\section{Methods}

This prospective study was approved by the ethics committee, and 42 patients diagnosed between 2012 and 2019 at Adana Numune Training and Research Hospital and followed up without treatment and 41 healthy controls were evaluated. Written informed consent was obtained from patients and healthy volunteers. The diagnosis of CLL was made according to iw CLL [17] and the patients were staged according to Rai staging system [18]. The data included gender; age; white blood cell count (WBC); lymphocyte count; hemoglobin ( $\mathrm{Hb})$ level; platelet count; presence of Del13q14, p53. Blood samples were drawn from the subjects and centrifuged at $4000 \mathrm{rpm}$ for $10 \mathrm{~min}$ and stored at $-80^{\circ} \mathrm{C}$ as serum until use. Serum ELA levels were measured by by using enzyme-linked immunosorbent assay (ELISA) kits (Dhanghai Sunred Biological Technology co. Ltd), automated ELISA reader (Thermo Scientific, FINLAND) and computer program (Scanlt for Multiscan F.C.2.5.1) in accordance with the manufacturer's instructions. Sensitivity was $0,118 \mathrm{ng} / \mathrm{ml}$ and assay rangewas $0,15 \mathrm{ng} / \mathrm{ml}-40$ $\mathrm{ng} / \mathrm{ml}$. Intra-Assay $\% \mathrm{CV}$ was $<\% 10$ and inter- assay $\% \mathrm{CV}$ was $<\% 12$ 'dir. The results were expressed as $\mathrm{ng} / \mathrm{ml}$.

\section{Statistical analysis}

Statistical analysis was made by Statistical Package for Social Sciences (SPSS) for Windows 20 (IBM SPSS Inc., Chicago, IL) ve MedCalc programs. The normality of the data was evaluated by Kolmogorov-Smirnov test. Data were described as numbers and percentage or median and range or mean \pm standart deviation, when appropriate. $\mathrm{T}$ test (for normally distrubeted data) and Mann Whitney U test for continuous values to campare the numeric values between the patient and control groups. $x^{2}$ Fisher's exact test was used for evaluating categorical values. ELA and variables related to CLL were correlated with Spearman correlation anlysis test. ROC analysis and Youden index method were used to determine a cut off point for ELA. All $p$-values were 2-sided with statistical significance at 0.05 alpha levels.

\section{Results}

The study population comprised 83 subjects: 41 in the control group and 42 with CLL. There was no significant difference between the CLL and control group in mean age $(63.9 \pm 9.8$ vs. $61.7 \pm 10.2, P=0.332)$. The ratio of male patients was higher in the CLL group than in the control group $(66.7 \%$ vs. $39 \%, P=0.016)$ (Table 1$)$.

There was no significant difference between the CLL and control group in mean haemoglobin levels $(12.5 \pm 2.2$ $\mathrm{g} / \mathrm{dL}$ vs. $12.7 \pm 2 \mathrm{~g} / \mathrm{dL}, P=0.707)$ and median neutrophil levels $\left(5.5 \times 10^{3} / \mu \mathrm{L}\right.$ vs. $\left.4.6 \times 10^{3} / \mu \mathrm{L}, P=0.078\right)$. However, median white blood cell (WBC) count $\left(27.1 \times 10^{3}\right.$ cells $/ \mu \mathrm{L}$ vs. $7.7 \times 10^{3}$ cells $\left./ \mu \mathrm{L}, P<0.001\right)$, median lymphocyte count 
Table 1 Demographic and laboratory findings in the control and CLL groups

\begin{tabular}{|c|c|c|c|c|}
\hline Variables & Entire population $N=83$ & CLL group $N=42$ & Control group $N=41$ & $p$ \\
\hline Age (years) & $62.8 \pm 10.0$ & $63.9 \pm 9.8$ & $61.7 \pm 10.2$ & 0.326 \\
\hline \multicolumn{5}{|l|}{ Gender } \\
\hline Female & $39(47.0)$ & $14(33.3)$ & $25(61.0)$ & \multirow[t]{2}{*}{$0.016^{*}$} \\
\hline Male & $44(53.0)$ & $28(66.7)$ & $16(39.0)$ & \\
\hline Haemoglobin (g/dL) & $12.6 \pm 2.1$ & $12.5 \pm 2.2$ & $12.7 \pm 2.0$ & 0.707 \\
\hline WBCs $\left(\times 10^{3} / \mu \mathrm{L}\right)$ & $13.7(2.6-131)$ & $27.1(5.8-131)$ & $7.7(2.6-16.3)$ & $<0.001^{*}$ \\
\hline Neutrophils $\left(\times 10^{3} / \mu \mathrm{L}\right)$ & $4.7(0.6-11.7)$ & $5.5(0.6-11.5)$ & $4.6(1.9-11.7)$ & 0.078 \\
\hline Lymphocytes $\left(\times 10^{3} / \mu \mathrm{L}\right)$ & $5(0.4-123)$ & $21.3(5-123)$ & $2.1(0.4-4.1)$ & $<0.001^{*}$ \\
\hline Platelets $\left(\times 10^{3} / \mu \mathrm{L}\right)$ & $225(24-630)$ & $200(24-463)$ & $253(49-630)$ & $0.008^{*}$ \\
\hline ELABELA (ng/ml) & $4.6(0.1-19.7)$ & $6.7(0.6-19.7)$ & $2(0.1-8.6)$ & $<0.001^{*}$ \\
\hline
\end{tabular}

Numerical variables are presented as mean \pm standard deviation or median (min-max) according to normality distribution. Categorical variables are presented as number (\%)

${ }^{*} P<0.05$ indicates statistical significance

Abbreviations: CLL Chronic lymphocytic leukaemia, WBC White blood cell

$\left(21.3 \times 10^{3}\right.$ cells $/ \mu \mathrm{L}$ vs. $2.1 \times 10^{3}$ cells $\left./ \mu \mathrm{L}, \mathrm{P}<0.001\right)$ and median ELA levels $(6.7 \mathrm{ng} / \mathrm{ml}$ vs. $2 \mathrm{ng} / \mathrm{ml}, \mathrm{P}<0.001)$ were found to be higher in the CLL group than in the control group (Fig. 1), whereas the median platelet level was lower in the CLL group than in the control group $\left(200 \times 10^{3} / \mu \mathrm{L}\right.$ vs. $\left.253 \times 10^{3} / \mu \mathrm{L}, P=0.008\right)$ (Table 1 ).

In the control and CLL groups, the ELA level did not exhibit a significant correlation with gender and age (Table 2).

The disease duration was 2-84 months in the CLL group, and the median disease duration was 24 months.
Further, $23.8 \%$ of the patients $(n=10)$ had stage $2,14.3 \%$ $(n=6)$ had stage 3 and $7.1 \%(n=3)$ had stage 4 disease. The direct coombs (DC) test was performed in all patients with CLL, and $11.9 \%(n=5)$ were positive. The p53 test was performed in 21 patients, and $28.6 \%(n=6)$ were positive. The del13q test was performed in $14 \mathrm{pa}$ tients, and $64.3 \%(n=9)$ were positive.

Among patients with CLL, ELA levels did not significantly differ according to the disease stage and between patients with positive and negative DC test results, patients with

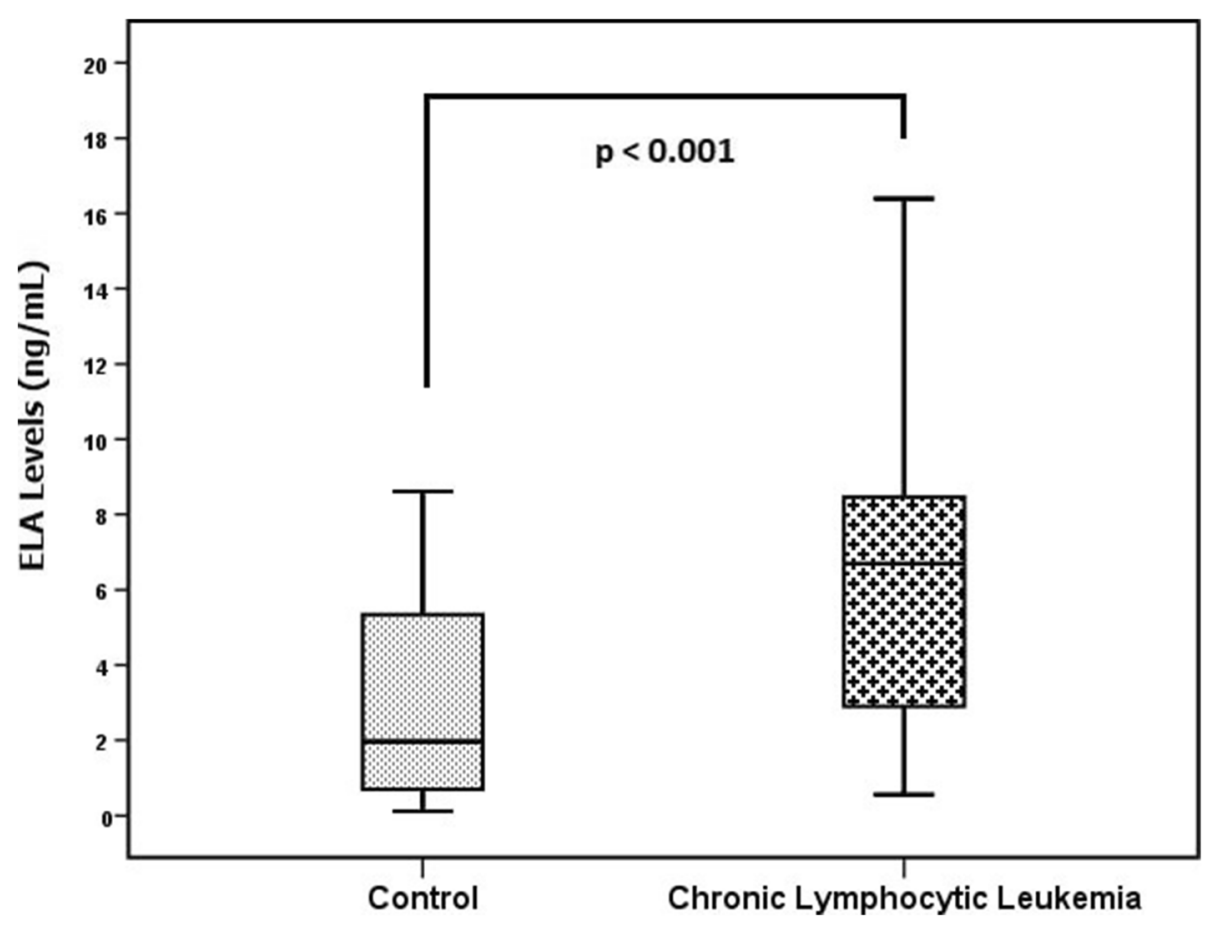

Fig. 1 Mean ELA levels in the control and CLL groups 
Table 2 ELABELA levels according to demographic findings in patients with CLL

\begin{tabular}{llll}
\hline Group & Variables & $\operatorname{ELABELA}(\mathrm{ng} / \mathrm{ml})$ & $\mathrm{p}$ \\
\hline CLL & Gender & & \\
& Female & $8.6(0.6-19.7)$ & 0.062 \\
& Male & $6.3(0.6-11)$ & \\
& Age & $r=0.056$ & 0.728 \\
Control & Gender & & \\
& Female & $3.5(0.2-8.6)$ & 0.234 \\
& Male & $1.3(0.1-7.0)$ & \\
& Age & $r=-0.003$ & 0.985 \\
\hline
\end{tabular}

ELABELA levels is presented as median (min-max)

$r=$ Spearman's correlation coefficient

Abbreviations: CLL Chronic lymphocytic leukaemia

positive and negative p53 test results and between patients with positive and negative delq13 test results (Table 3).

There was a positive correlation between ELA levels and WBC count $(\mathrm{r}=0.357, P=0.001)$ and lymphocyte count $(\mathrm{r}=0.362, \mathrm{P}=0.001)$ in the study population (Fig. 2). No correlation was found between ELAlevels and other laboratory findings. In patients with CLL, there was no significant relationship between ELA levels and disease duration, stage and laboratory findings (Table 4).

In the multivariate logistic regression model, gender, WBC count, platelet levels and ELA levels were found to

Table 3 ELABELA levels according to disease stage and tests in patients with CLL

\begin{tabular}{llll}
\hline Variables & CLL & ELABELA (ng/ml) & $p$ \\
\hline STAGE & $\mathrm{N}=42$ & & \\
0 & $7(16.7)$ & $7.6(6.2-19.6)$ & 0.361 \\
1 & $16(38.1)$ & $6.3(0.6-19.7)$ & \\
2 & $10(23.8)$ & $6.3(0.6-9.7)$ & \\
3 & $6(14.3)$ & $6.4(0.7-15.8)$ & \\
4 & $3(7.1)$ & $4.8(1.1-7.3)$ & 0.134 \\
DC & $N=42$ & & \\
Negative & $34(81.0)$ & $7(0.6-19.7)$ & 0.080 \\
Positive & $5(11.9)$ & $2.9(0.7-6.9)$ & \\
Weak positive & $3(7.1)$ & $3(1.1-19.6)$ & \\
P53 & $N=21$ & & 0.898 \\
Negative & $15(71.4)$ & $7.6(0.7-19.7)$ & \\
Positive & $6(28.6)$ & $3.4(0.6-8.8)$ & \\
DEL13q & $N=14$ & & \\
Negative & $5(35.7)$ & $6.2(0.7-9.7)$ & \\
Positive & $9(64.3)$ & $6.6(0.6-16.4)$ & \\
\hline
\end{tabular}

ELABELA level is presented as median (min-max). Categorical variables are presented as number (\%)

Abbreviations: CLL Chronic lymphocytic leukaemia be associated with CLL. Furthermore, WBC count and ELA levels were identified as independent risk factors for predicting CLL (WBC: $\mathrm{OR}=1.58, P<0.001$; ELA: $\mathrm{OR}=1.38, \mathrm{P}<0.001)$ (Table 5).

The cut-off value for WBC in predicting CLL was found to be $>13.9$, with $92.9 \%$ sensitivity and $97.6 \%$ specificity (+PV: $97.5 \%,-\mathrm{PV}: 93 \%, \mathrm{AUC} \pm \mathrm{SE}=0.965 \pm$ $0.023, \mathrm{P}<0.001)$. The cut-off value for ELA level in predicting CLL was found to be $>5.34$, with $66.7 \%$ sensitivity and $75.6 \%$ specificity (+PV: $73.7 \%,-\mathrm{PV}: 68.9 \%$, $\mathrm{AUC} \pm \mathrm{SE}=0.738 \pm 0.054, \mathrm{P}<0.001$ ) (Fig. 3).

In patients with CLL, the ratio of DC-negative patients was found to be higher in patients with an ELA level > $5.34(\mathrm{ng} / \mathrm{ml})$ compared with those with an ELA level of $\leq 5.34(92.9 \%$ vs. $57.1 \%, P=0.011)$. In patients with CLL, there was no significant relationship between patients with an ELA level $>5.34(\mathrm{ng} / \mathrm{ml})$ and patients with an ELA level of $\leq 5.34(\mathrm{ng} / \mathrm{ml})$ in demographic parameters and other clinical findings (Table 6).

\section{Discussion}

Previous studies have shown that ELA possesses antiapoptototic activity $[15,19]$. Although the role of ELA in cancer has been investigated in a limited number of studies [20, 21], several studies have shown that apelin, which is the other endogenous ligand of APRLN, is overexpressed in many tumour tissues and cell lines, and the apelin/APLNR system plays a role in the regulation of cancer cell growth and migration [22-24].

In the present study, ELA levels were significantly higher in patients with CLL than in control group patients. This finding supports the anti-apoptotic effects of ELA and the apelinergic system reported in the literature.

Seo et al. showed that DNA damage-induced hnRNP L upregulates $p 53$ expression [25].

Li et al. showed that ELA downregulates the interaction between hnRNPL and p53 [26], resulting in an antiapoptotic effect. Additionally, Ganguly et al. reported increased ELA gene expression levels in glioblastoma cells and that an association exists between upregulated expression of ELA and poor prognosis [21]. Yi et al. reported increased ELA expression levels in ovarian cancer cells. Disruption of ELA expression in these cell lines suppressed cell growth, cell migration and cell cycle progression. They showed that ELA exerted this effect independently of APLNR, affecting cell growth and cell cycle progression in a $p 53$-dependent manner. Loss of ELA in cells expressing high levels of $p 53$ caused a decrease in cell number due to cell death, and this resulted from p53-induced cell apoptosis [20]. Mouse double minute 2 (MDM2) is a critical negative regulator of tumour suppressor p53 and plays a key role in controlling its transcriptional activity, protein stability and nuclear localisation. MDM2 expression is upregulated in many cancers, resulting in a loss 


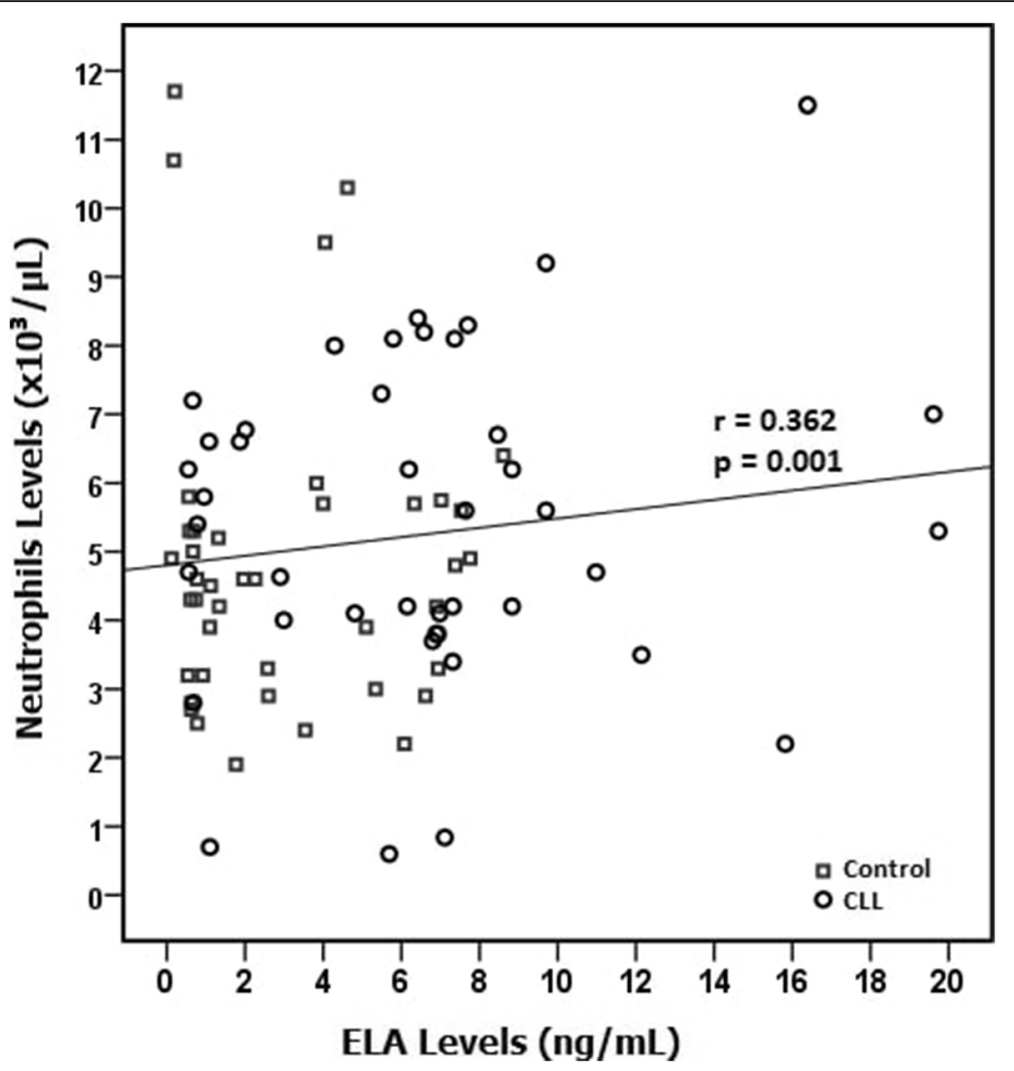

Fig. 2 Relationship between ELA levels and neutrophil levels

of p53-dependent activities, such as apoptosis and cell cycle arrest [27]. The PI3K/Akt signalling pathway has been shown to play a critical role in the tumourigenesis of haematopoietic cells. Activation of the PI3K/Akt pathway occurs even in the early stages of tumour development, and it correlates with poor prognosis and therapeutic resistance in various human cancers $[15,28]$. ELA activates the PI3K/AKT/mTORC1 signal to promote the progression of $\mathrm{hESC}$ cell cycle and protein translation and blocks stress-induced apoptosis. These

Table 4 Clinical findings related to ELABELA levels in patients with CLL

\begin{tabular}{|c|c|c|c|c|}
\hline \multirow[t]{3}{*}{ Variables } & \multicolumn{2}{|c|}{ Study population } & \multicolumn{2}{|l|}{$\mathrm{CLL}$} \\
\hline & \multicolumn{2}{|c|}{ ELABELA } & \multicolumn{2}{|c|}{ ELABELA } \\
\hline & $r$ & $p$ & $r$ & $p$ \\
\hline Disease duration & - & - & -0.153 & 0.332 \\
\hline Stage & - & - & -0.246 & 0.116 \\
\hline Haemoglobin & 0.050 & 0.655 & 0.087 & 0.582 \\
\hline WBC & 0.357 & $0.001^{*}$ & 0.087 & 0.585 \\
\hline Neutrophil & 0.091 & 0.411 & 0.051 & 0.748 \\
\hline Lymphocyte & 0.362 & $0.001^{*}$ & 0.068 & 0.667 \\
\hline Platelet & -0.202 & 0.067 & -0.041 & 0.797 \\
\hline
\end{tabular}

$r=$ Spearman's correlation coefficient Abbreviations: WBC White blood cell pathways are the main signals reported to be correlated with apoptosis. MDM2 also inhibits p53 through this pathway. It has been suggested that the apelinergic system may inhibit apoptosis through these common pathways $(7-11,28)$.

hnRNPC is a negative regulator of p53. A previous study showed that the 1-41 p53 region, which is the region where $\mathrm{p} 53$ binds to $\mathrm{Mdm} 2$, also interacts with hnRNPC. These results show that hnRNPC may be synergistic with $\mathrm{Mdm} 2$ in regulating p53 stability.

Table 5 Risk factors for CLL

\begin{tabular}{|c|c|c|c|c|c|c|}
\hline \multirow[t]{2}{*}{ Variables } & \multicolumn{3}{|c|}{ Univariate } & \multicolumn{3}{|c|}{ Multivariate } \\
\hline & $\mathrm{OR}$ & $95 \% \mathrm{Cl}$ & $\mathrm{p}$ & $\mathrm{OR}$ & $95 \% \mathrm{Cl}$ & $p$ \\
\hline \multicolumn{7}{|l|}{ Gender } \\
\hline Female & ref & & & & & \\
\hline Male & 3.13 & $1.27-7.67$ & $0.013^{*}$ & & & \\
\hline WBC & 1.61 & $1.29-2.00$ & $<0.001^{*}$ & 1.58 & $1.26-2.01$ & $<0.001^{*}$ \\
\hline Neutrophil & 1.13 & $0.93-1.37$ & 0.229 & & & \\
\hline Platelet & 0.98 & $0.97-0.98$ & $0.026^{*}$ & & & \\
\hline \multirow[t]{2}{*}{ ELABELA } & 1.31 & $1.13-1.52$ & $<0.001^{*}$ & 1.38 & $1.17-1.63$ & $<0.001^{*}$ \\
\hline & & & & \multicolumn{3}{|c|}{ Nagelkerke $R^{2}=0.849 ; p<0.001^{*}$} \\
\hline
\end{tabular}

Abbreviations: OR Odds ratio, $\mathrm{Cl}$ Confidence intervals ${ }^{*} P<0.05$ indicates statistical significance 


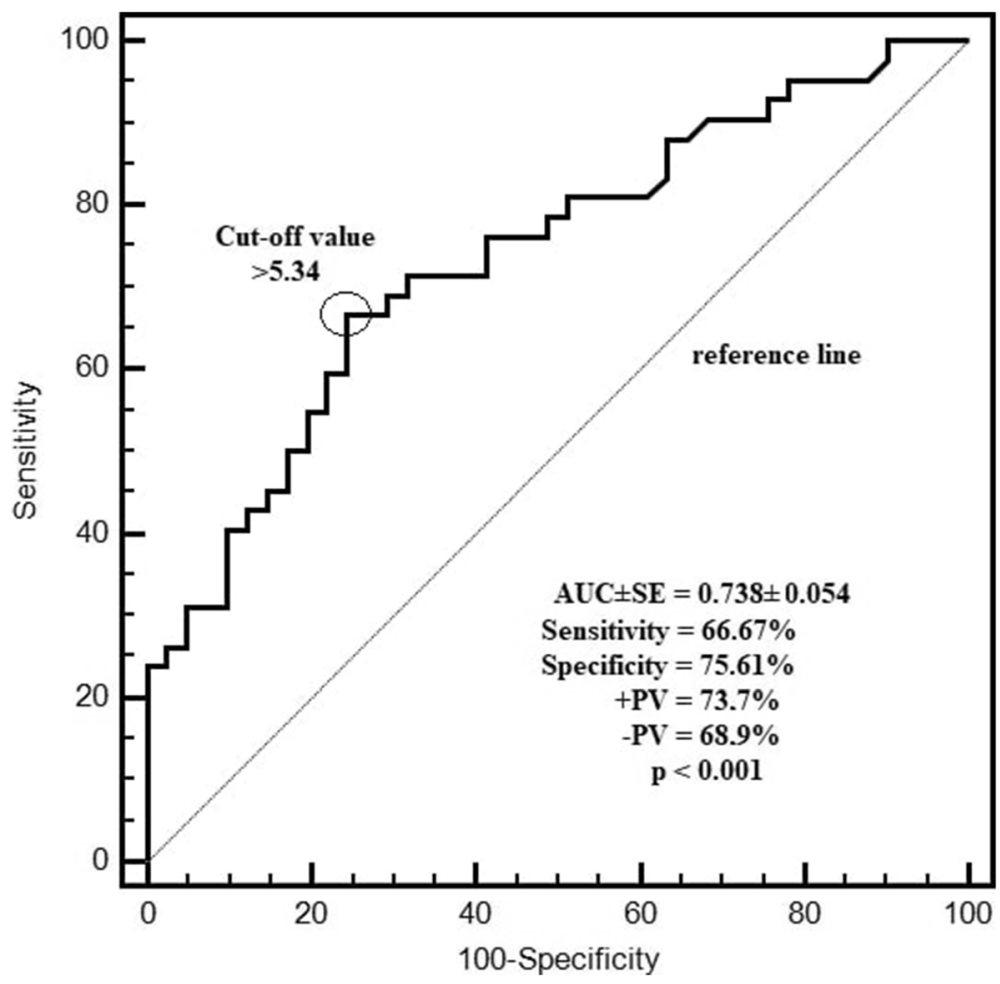

Fig. 3 Evaluation of the diagnostic performance of ELA level in predicting CLL

Doxorubicin competes with p53 for binding to the RNA recognition motif of hnRNPC, thereby enhancing p53 stability and triggering p53-dependent apoptosis [29]. ELA, which has been shown to possess anti-apoptotic activity, has been shown to interact with the CXCR4a signalling pathway, one of the chemokines $[15,19]$. Chemokines are produced by cancer-associated fibroblasts, a component of stromal cells, and affect metastatic potential and site-specific spread of cancer cells. The stromal cell-derived factor-1 (SDF-1/CXCL12) belongs to the family of CXC chemokines. The effects of CXCL12 in many cancer types, including its role in promoting local invasion and distant metastasis from lung cancer metastasis, have been described [30-32]. Wang et al. showed that CXCL12 blocks apoptosis in human adenocarcinoma cell line via CXCR4. They observed that the expression levels of $\mathrm{Bcl}-2$ and bcl-xl in the adenocarcinoma cell line increased with CXCL12 therapy and decreased with CXCR4 antagonist and JAK2 inhibitor therapy [33]. In summary, ELA and the apelinergic system have been shown to inhibit apoptosis in several steps (via bcl-2, bcl-xl, mdm2, hnRPLN, p53, and PI3K/Akt/mTORC1). Based on these results, it can be suggested that ELA and the apelinergic system play a central role in the pathogenesis of CLL.
In the present study, we showed that serum ELA levels were significantly high in patients with CLL. This finding indicates that ELA contributes to the development of CLL, which is consistent with the findings of other studies in the literature.

Venetoclax is a bcl-2 inhibitor and idasanutlin is a MDM2 inhibitor, and both are indicated for use in CLL. Venetoclax + idasanutlin have been suggested to be an effective treatment for relapsed/refractory acute myeloid leukaemia (AML) [34]. However, inhibition of ELA or the apelinergic system will exert the effect of both venetoclax and idasanutlin. In other words, inhibition of the apelinergic system alone can provide a treatment as effective as venetoclax and idasanutlin or even a combination of the two. Yi et al. showed that human ELA can downregulate p53 protein levels and activity in cancer cells instead of working as a p53 activator. Although ovarian cancer cells are typically normal type p53, no studies have assessed whether there is a correlation between p53 mutation status and ELA expression levels in ovarian cancer [20].

Because the number of patients with TP53 mutation was insufficient in the present study, we could not perform a statistically significant evaluation. However, future studies evaluating a sufficient number of patients will be valuable for CLL, in which TP53 mutations 
Table 6 Demographic characteristics and clinical findings according to the cut-off ELABELA levels in predicting CLL

\begin{tabular}{|c|c|c|c|}
\hline \multirow[t]{2}{*}{ Variables } & \multicolumn{2}{|l|}{$\underline{\text { ELABELA }(\mathrm{ng} / \mathrm{ml})}$} & \multirow[t]{2}{*}{$p$} \\
\hline & $\begin{array}{l}\leq 5.34 \\
N=14\end{array}$ & $\begin{array}{l}>5.34 \\
N=28 \\
\end{array}$ & \\
\hline Age (years) & $63.7 \pm 8.3$ & $63.9 \pm 10.6$ & 0.948 \\
\hline \multicolumn{4}{|l|}{ Gender } \\
\hline Female & $4(28.6)$ & $10(35.7)$ & \multirow[t]{2}{*}{0.908} \\
\hline Male & $10(71.4)$ & $18(64.3)$ & \\
\hline Disease duration (months) & $30(2-72)$ & $24(2-84)$ & 0.398 \\
\hline \multicolumn{4}{|l|}{ Stage } \\
\hline 0 & - & $7(25.0)$ & \multirow[t]{5}{*}{0.231} \\
\hline 1 & $6(42.9)$ & $10(35.7)$ & \\
\hline 2 & $4(28.6)$ & $6(21.4)$ & \\
\hline 3 & $2(14.3)$ & $4(14.3)$ & \\
\hline 4 & $2(14.3)$ & $1(3.6)$ & \\
\hline \multicolumn{4}{|l|}{ DC } \\
\hline Negative & $8(57.1)$ & $26(92.9)$ & \multirow[t]{3}{*}{$0.011^{*}$} \\
\hline Positive & $4(28.6)$ & $1(3.6)$ & \\
\hline Weak positive & $2(14.3)$ & $1(3.6)$ & \\
\hline \multicolumn{4}{|l|}{ p53 } \\
\hline Negative & $3(50.0)$ & $12(80.0)$ & \multirow[t]{2}{*}{0.401} \\
\hline Positive & $3(50.0)$ & $3(20.0)$ & \\
\hline \multicolumn{4}{|l|}{ DEL13q } \\
\hline Negative & $1(25.0)$ & $4(40.0)$ & \multirow[t]{2}{*}{0.999} \\
\hline Positive & $3(75.0)$ & $6(60.0)$ & \\
\hline Haemoglobin (g/dL) & $12 \pm 2.2$ & $12.7 \pm 2.2$ & 0.327 \\
\hline WBCs $\left(\times 10^{3} / \mu \mathrm{L}\right)$ & $29.6(5.8-128.7)$ & $25.3(6.4-131)$ & 0.539 \\
\hline Neutrophils $\left(\times 10^{3} / \mu \mathrm{L}\right)$ & $5.6(0.7-8)$ & $5.5(0.6-11.5)$ & 0.831 \\
\hline Lymphocytes $\left(\times 10^{3} / \mu \mathrm{L}\right)$ & $24.3(5-123)$ & $17.5(5.2-116.5)$ & 0.496 \\
\hline Platelets $\left(\times 10^{3} / \mu \mathrm{L}\right)$ & $200(81-463)$ & $200(24-350)$ & 0.800 \\
\hline
\end{tabular}

Numerical variables are presented as mean \pm standard deviation or median (min-max) according to normality distribution. Categorical variables are presented as number (\%)

${ }^{*} P<0.05$ indicates statistical significance

Abbreviations: CLL Chronic lymphocytic leukaemia, WBC White blood cell

occur frequent. The results of our study provide evidence that ELA and the apelinergic system can be valuable in targeted therapy and may also be useful in predicting patient prognosis, response to treatment and follow-up. More comprehensive studies are needed to address these issues.

\section{Conclusions}

This study highlights the effects of ELA on CLL and emphasizes that ELA targeting may be a potential therapeutic option for treating CLL.

\section{Abbreviations}

Cl: Confidence intervals; CLL: Chronic lymphocytic leukemia; ELISA: Enzymelinked immunosorbent assay; Hb: Hemoglobin; OR: Odds ratio; PLT: Platelet; WBC: White blood cell count

\section{Acknowledgements}

Not applicable.

\section{Authors' contributions}

The author(s) have made the following declarations regarding their contributions: DYA: Designed the study, collected data and approved the final manuscript. MB: Informing patients and volunteers and obtaining their consent. Prepared the samples. FAB: Performed the experiments. BA: Analyzed the data. All authors (DYA, MB, FAB, BA) read and approved the final manuscript.

\section{Funding}

No funding.

Availability of data and materials

The datasets generated for this study are available from the corresponding author on reasonable request. The authors declare that all other data supporting the findings of this study are available within the article and its Supplementary Information Files. Additional files.

Ethics approval and consent to participate

Ethics committee approval was received. The non-invasive clinical research ethics committee of T. C. Cukurova University Faculty of Medicine convened on 5 October 2018 and approved the study. Written informed consent was obtained from patients and healthy volunteers. The ethics committee decision is attached.

\section{Consent for publication}

Not applicable.

\section{Competing interests}

All authors are aware of the consent and agree with the submission. The authors declare no conflict of interest or competing interests. No changes will be made to the authors

\section{Author details}

'Department of Internal Medicine and Haematology, Adana City Education and Research Hospital, Mithat Özsan Bulvarı Kışla Mah. 4522 Sok. No:1, 01260 Yüreğir, Adana, Turkey. ${ }^{2}$ Department of Internal Medicine, Adana City Training and Research Hospital, Mithat Özsan Bulvarı Kışla Mah. 4522 Sok. No:1, 01260 Yüreğir, Adana, Turkey. ${ }^{3}$ Department of Biochemistry, Kahramanmaraş Sütçü Imam University Faculty of Medicine, Mithat Özsan Bulvarı Kışla Mah. 4522 Sok. No:1, 01260 Yüreğir, Adana, Turkey. ${ }^{4}$ Department of Internal Medicine and Haematology, Adana City Education and Research Hospital, Mithat Özsan Bulvarı Kışla Mah. 4522 Sok. No:1, 01260 Yüreğir, Adana, Turkey.

Received: 21 June 2019 Accepted: 1 November 2019 Published online: 12 November 2019

\section{References}

1. Redaelli A, et al. The clinical and epidemiological burden of chronic lymphocytic leukaemia. Eur J Cancer Care. 2004;13(3):279-87.

2. Kipps TJ, et al. Chronic lymphocytic leukaemia. Nat Rev Dis Primers. 2017:3:6096.

3. Kitada S, Andersen J, Akar S, Zapata JM, Takayama S, Krajewski S, Wang HG, Zhang X, Bullrich F, Croce CM, Rai K, Hines J, Reed JC. Expression of apoptosis-regulating proteins in chronic lymphocytic leukemia: correlations with in vitro and in vivo chemoresponses. Blood. 1998;91(9):3379-89.

4. Matthew S. Davids, Targeting BCL-2 in B-cell lymphomas. Blood, 31 August 2017. Volume 130, Number 9

5. Catherwood MA, et al. Relevance of TP53 for CLL diagnostics. J Clin Pathol 2019;0:1-4.

6. Shin et al., Apelinergic system structure and function. Compr Physiol. Author manuscript; available in PMC 2018 December 12.

7. Liu J, Liu M, Chen L. Regulation of apoptosis by Apelin/APJ system. Acta Biochim Biophys Sin. 2017;49(6):471-8.

8. Zhang Z, Yu B, Tao GZ. Apelin protects against cardiomyocyte apoptosis induced by glucose deprivation. Chin Med J. 2009;122:2360-5.

9. Xin M, Deng X. Nicotine inactivation of the proapoptotic function of Bax through phosphorylation. J Biol Chem. 2005;280:10781-9. 
10. Burgering BM, Medema RH. Decisions on life and death: FOXO Forkhead transcription factors are in command when PKB/Akt is off duty. J Leukoc Biol. 2003;73:689-701.

11. Mayo LD, Donner DB. The PTEN, Mdm2, p53 tumor suppressoroncoprotein network. Trends Biochem Sci. 2002;27:462-7.

12. Hassan AS, Hou J, Wei W, et al. Expression of two novel transcripts in the mouse definitive endoderm. Gene Expr Patterns. 2010;10:127-34.

13. Chng SC, Ho L, Tian J, et al. ELABELA: a hormone essential for heart development signals via the apelin receptor. Dev Cell. 2013;27:672-80

14. Pauli A, Norris ML, Valen E, et al. Toddler: an embryonic signal that promotes cell movement via Apelin receptors. Science. 2014;343:1248636.

15. Ho L, Tan SY, Wee $S$, et al. ELABELA is an endogenous growth factor that sustains hESC self-renewal via the PI3K/AKT pathway. Cell Stem Cell. 2015;17:435-47.

16. Li M, Gou H, Tripathi BK, et al. An Apela RNA-containing negative feedback loop regulates p53-mediated apoptosis in embryonic stem cells. Cell Stem Cell. 2015;16:669-83.

17. Hallek M, Cheson BD, Catovsky D, et al. Guidelines for the diagnosis and treatment of chronic lymphocytic leukemia: a report from the international workshop on chronic lymphocytic leukemia updating the National Cancer Institute-working group 1996 guidelines. Blood. 2008;111:5446-56.

18. Rai KR, Sawitsky A, Cronkite EP, et al. Clinical staging of chronic lymphocytic leukemia. Blood. 1975:46:219-34.

19. Norris ML. et al. Toddler signaling regulates mesodermal cell migration downstream of Nodal signaling. Elife. 2017 Nov 9;6. pii: e22626.

20. $Y_{i} Y$, et al. APELA promotes tumour growth and cell migration in ovarian cancer in a p53-dependent manner. Gynecol Oncol. 2017 Dec;147(3):663-71.

21. Ganguly D, et al. APELA Expression in Glioma, and Its Association with Patient Survival and Tumor Grade. Pharmaceuticals (Basel). 2019;12(1).

22. Peng $X$, Li F, Wang P, et al. Apelin-13 induces MCF-7 cell proliferation and invasion via phosphorylation of ERK1/2. Int J Mol Med. 2015;36:733-8.

23. Lv D, Li L, Lu Q, et al. PAK1-cofilin phosphorylation mediates human lung adenocarcinoma cells migration induced by apelin-13. Clin Exp Pharmacol Physiol. 2016:43:569-79.

24. Hoffmann M, Fiedor E, Ptak A. Bisphenol a and its derivatives tetrabromobisphenol a and tetrachlorobisphenol a induce apelin expression and secretion in ovarian cancer cells through a peroxisome proliferator-activated receptor gamma-dependent mechanism. Toxicol Lett. 2017;269:15-22.

25. Seo JY. et al. Heterogeneous nuclear ribonucleoprotein (hnRNP) L promotes DNA damage-induced cell apoptosis by enhancing the translation of p53. Oncotarget, 2017, Vol. 8, (No. 31), pp: 51108-51122.).

26. Li M, et al. An Apela RNA-containing negative feedback loop regulates p53mediated apoptosis in embryonic stem cells. Cell Stem Cell. 2015 Jun 4; 16(6):669-83.

27. Oliner JD, et al. The role of MDM2 amplification and overexpression in tumorigenesis. Cold Spring Harb Perspect Med. 2016 Jun; 1:6(6).

28. Kawauchi K, et al. The PI3K/Akt Pathway as a Target in the Treatment of Hematologic Malignancies. Anticancer Agents Med Chem. 2009;9(5):550-9e.

29. Yuan Shen et al. SNHG1 attenuates hnRNPC-p53 interaction. EMBO reports Vol 18, No 4, 2017

30. Wald O, Shapira OM, Izhar U. CXCR4/CXCL12 axis in non small cell lung cancer (NSCLC) pathologic roles and therapeutic potential. Theranostics. 2013;3(1):26-33.

31. Franco R, Pirozzi G, Scala S, et al. CXCL12-binding receptors expression in non-small cell lung cancer relates to tumoral microvascular density and CXCR4 positive circulating tumoral cells in lung draining venous blood. Eur J Cardiothorac Surg. 2012;41(2):368-75.

32. Rodriguez-Lara V, Peña-Mirabal E, Baez-Saldaña R, et al. Estrogen receptor beta and CXCR4/CXCL12 expression: differences by sex and hor monal status in lung adenocarcinoma. Arch Med Res. 2014:45(2):158-69.

33. Wang $\mathrm{M}$, et al. CXCL12 suppresses cisplatin-induced apoptosis through activation of JAK2/STAT3 signaling in human non-small-cell lung cancer cells. OncoTargets and Therapy. 2017;10:3215-24.

34. Droegemeier K, et al. BCL2/MDM2 inhibitor combo effective in AML. Cancer Discov. 2019;9(2):156.

\section{Publisher's Note}

Springer Nature remains neutral with regard to jurisdictional claims in published maps and institutional affiliations.

Ready to submit your research? Choose BMC and benefit from:

- fast, convenient online submission

- thorough peer review by experienced researchers in your field

- rapid publication on acceptance

- support for research data, including large and complex data types

- gold Open Access which fosters wider collaboration and increased citations

- maximum visibility for your research: over $100 \mathrm{M}$ website views per year

At BMC, research is always in progress.

Learn more biomedcentral.com/submissions 